\title{
RESENHA
}

\section{ORIGENS DA HABITAÇÃO SOCIAL NO BRASIL: ARQUITETURA MODERNA, LEI DO INQUILINATO E DIFUSÃO DA CASA PRÓPRIA}

\author{
Nabil Bonduki \\ São Paulo, Estação Liberdade, 2004 (4ª ed.) 344 p.: il.
}

Para quem deseja reavaliar seus conceitos sobre as relações entre o Estado e a habitação no Brasil, especialmente na era Vargas, este livro apresenta questões e perspectivas realmente inovadoras, construídas através de uma profunda investigação da documentação de instituições e pessoas que estiveram à frente das propostas da habitação social no Brasil, o que levou a ANPUR a dar-lhe o Primeiro Prêmio Brasileiro de Política e Planejamento Urbano e Regional na categoria livro. O grande objetivo do trabalho é mostrar como o agravamento da falta de moradia nas cidades brasileiras se transformou em uma questão social nas primeiras décadas do século XX e, principalmente, como o Estado respondeu a esta questão de 1930 a 1964, destacando-se a lei do inquilinato e a produção de moradias pelos Institutos de Aposentadorias e Pensões (IAPs) e a Fundação da Casa Popular (FCP).

Nabil Bonduki é professor do departamento de Arquitetura e Urbanismo da Escola de Engenharia de São Carlos da USP, e também uma das maiores autoridades sobre o problema habitacional brasileiro. $\mathrm{O}$ núcleo do livro é proveniente de sua tese de doutorado "Origens da habitação social no Brasil: o caso de São Paulo (1930-1954), FAU-USP, 1994”, à qual foi acrescida outra pesquisa sobre diversas cidades brasileiras, com destaque para o Rio de Janeiro, São Paulo, Belo Horizonte, Porto Alegre e Recife, onde as experiências de produção 
estatal da moradia foram mais expressivas. Pode-se dizer que é uma síntese de longa trajetória dedicada à habitação popular, iniciada no final dos anos $1970 \mathrm{com}$ estudos sobre a auto-construção na periferia de São Paulo, e que também passou por experiências de formulação de políticas públicas junto aos movimentos sociais e como Superintendente de Habitação Popular da Prefeitura de São Paulo durante o governo Luiza Erundina (1989-1992).

Em sete capítulos o livro começa revendo as características que marcaram a questão da habitação social na República Velha: a produção rentista e o sanitarismo. Na seqüência analisa-se o debate sobre habitação no período Vargas com suas diversas correntes e propostas, as origens da habitação social, a produção estatal pelos IAPs e a FCP e suas relações com a arquitetura moderna, a intervenção no mercado de locação através do congelamento dos aluguéis e a lei do inquilinato. O livro termina tratando da crise da habitação nos anos 40 e a generalização da favela, das periferias e da autoconstrução, onde a habitação fica por conta do trabalhador, como um resultado dos limites da intervenção do Estado na habitação social no período entre 1930-1964.

Entre os muitos méritos que podem ser ressaltados neste trabalho, merece destaque o fato de ele não sofrer de certo maniqueísmo anti-populista ao tratar as relações de Vargas com a habitação social, o que lhe permite não reduzi-la, como é tradicional na literatura, a uma mera enganação populista, sem maiores conseqüências para o estoque de moradias e o espaço das cidades. Assim, exibindo números e cálculos detalhados da produção de moradias pelos IAPs e a FCP mostrase que esta foi muito mais significativa do que supõe o maniqueísmo anti-populista, atingindo cerca de 140 mil unidades, o suficiente para atender à demanda de $10 \%$ da população em cidades brasileiras com mais de 50 mil habitantes. E, mais importante ainda, deixa-se claro que o fato de esta produção estatal ter sido indiscutivelmente insuficiente, como mostra a favelização e periferização de nossas cidades, não autoriza a deduzir, como normalmente se faz, que as moradias financiadas e/ou construídas pelo Estado fossem numericamente inexpressivas.

A riqueza e a complexidade deste processo surgem com maior nitidez ainda quando Bonduki analisa esta produção estatal de moradias em termos qualitativos, isto é, os projetos das habitações e o que elas continham em termos de racionalidade econômica, conceitos de habitação social, de sociabilidade moderna, de desenvolvimento e estruturação urbana. A análise dos projetos habitacionais mostra que no Brasil se fez o que então de melhor se fazia no mundo nesta matéria, de acordo com os princípios estéticos e funcionais do urbanismo e da arquitetura modernista, que estavam associadas à incorporação de tecnologias e da industrialização da construção civil, com o qual se esperava criar o novo trabalhador urbano integrado ao Estado do Bem Estar Social. Isto fica claro quando nos anos 40 passou-se a privilegiar a construção de conjuntos verticais em substituição a bairros com casas isoladas em centro de terreno, que predominavam 
até então. Inicia-se aí um ciclo de conjuntos verticais com forte influência dos grandes projetos que no entre-guerras foram construídos pela social democracia na Alemanha, "Siedlungen", na Áustria, "Höfes" vienenses e, na França, "unités d'habitation" corbusianas, além de cidades ou bairros-jardins que às vezes se misturavam com outras tendências modernas.

O livro apresenta rico material fotográfico sobre estes conjuntos de grandes dimensões, projetados para mais de 3.000 pessoas, bem providos de serviços e infra-estrutura e relativamente bem acessíveis. O Rio de Janeiro possui vários de seus exemplares e foi aqui que o primeiro deles foi edificado, o Conjunto Residencial Realengo do IAPI, concluído em 1943. Acessível pela ferrovia e composto por 21344 unidades, capaz de abrigar cerca de 14000 pessoas, ali foi implantada uma infra-estrutura completa (água, esgoto, iluminação, pavimentação e até estação de tratamento de esgoto, algo que ainda hoje é considerado um luxo), e mais serviços coletivos como escola primária, creche, ambulatório médico e gabinete dentário, quadra de esportes, enfim, uma paisagem de "welfare state" que poderia estar em cidades do capitalismo central. Nesta mesma linha foram erguidos conjuntos em Del Castillo (1.520 unidades) Bangu (5.000 unidades), Várzea do Carmo (São Paulo, 4.038 unidades), Passo de Areia (Porto Alegre, 2.496), Vila Guiomar (Santo André, 3.000 unidades), Areias (Recife, 1.450 unidades) para ficar em alguns exemplos.

Este redimensionamento da produção estatal da moradia durante o nacionaldesenvolvimentismo é alcançado na obra quando é descrita a participação de seus principais formuladores e executores, ou seja, os arquitetos, os técnicos dos ministérios e prefeituras, os políticos, inclusive o próprio Vargas, que chegou a propor a criação de um órgão central de política habitacional em 1944, o que só veio a ocorrer em 1964 com a criação do BNH. Para tanto, é recuperada a transformação da habitação de uma questão de mercado para uma questão de Estado, de justiça social, desenvolvimento industrial e estabilidade política, inflexão que em toda parte começou na conjuntura da depois da Primeira Guerra e se consolidou durante a Segunda Guerra Mundial. Aliás, a grande tese de Bonduki é mostrar que o relativo fracasso da intervenção estatal se deu exatamente pela ausência de um órgão central capaz de implementar uma política de habitação, fórmula que foi bem sucedida na Europa, Estados Unidos e na Argentina, onde, na época do populismo peronista, "nuestros hermanos" atingiram índices iguais ou superiores aos países centrais em termos de atendimento ao direito de moradia.

A moradia popular se tornou uma questão social nos anos $30 \mathrm{em}$ todo o mundo e no Brasil, quando finalmente foi vencida a férrea resistência liberal à intervenção do Estado nesta e em muitas outras questões sociais e econômicas. Tal consenso foi construído em parte através da participação de profissionais 'e intelectuais em debates e seminários promovidos por entidades públicas e privadas. Bonduki dá especial atenção ao I Congresso de Habitação realizado pelo Instituto 
de Engenharia, em 1931, e às Jornadas de Habitação promovidas pelo IDORT, em 1941, ambos em São Paulo. Nos dois eventos registrou-se grande interesse do público, sendo notável que para o segundo foram convidados líderes industriais como Roberto Simonsen e diversos professores da USP, dentre eles Pierre Monbeig. De modo mais específico, os arquitetos organizados através do IAB debateram e apresentaram projetos para a habitação popular em seus congressos e inúmeras revistas. Segundo o autor:

Ao contrário do que ocorrera na República Velha, a construção de um modelo de habitação operária não era apenas um discurso ideológico desvinculado de estratégias concretas. Houve um esforço visível para dar viabilidade às novas propostas (...) e tornou-se urgente encontrar soluções habitacionais compatíveis com o novo ciclo de expansão econômica e com o desenvolvimentismo (BONDUKI, 2004:76, 77).

Após este mergulho no problema habitacional brasileiro durante o desenvolvimentismo, fica a certeza de que os limites da intervenção estatal em nosso caso não seu deu por conta da falta de capacitação técnica, econômica ou financeira, como se pode ver pela quantidade, tamanho, rapidez de execução e, sobretudo, pela qualidade e inovação dos projetos. Revendo o modo como muitos se dedicaram à questão no Brasil, inclusive Getúlio Vargas, pode-se lembrar o que Henri Lefebvre nos diz sobre os esforços da França da terceira república em promover a casa proletária no subúrbio, processo em que ele nota o sincero desejo das classes dominantes de assim moralizar o proletariado. $O$ que de fato esteve ausente durante todo o tempo foi uma política habitacional, através da qual se faria a centralização e a coordenação das diversas iniciativas estatais fragmentadas entre os diversos IAPs, FCP e outros órgãos estatais, o que, com defasagem, só foi atingido com a ditadura de 1964 e a criação do BNH. E, definitivamente, o caso de uma Argentina que obtém um êxito muito superior ao do Brasil nesta matéria, onde havia o mesmo jogo político do populismo com intensidade maior, mostra que a compreensão daquele período precisa ir além de certos esquemas explicativos tradicionais e também de mais estudos comparativos.

Nelson da Nóbrega Fernandes PPGEO-UFF 